\title{
Development of Small and Medium Enterprises (SMEs) Accounting Information System in Cluster of Kampung Laweyan Batik, Surakarta, Indonesia
}

\author{
Anita Wijayanti, Kartika Hendra Ts \\ University of Islam Batik, Surakarta, Indonesia
}

\begin{abstract}
The role of small and medium enterprises (SMEs) in the economy of a country was quite strategic, however the tightness of the competition, has allowed the SMEs into disadvantageous position. The SMEs need a precise accounting information system, thus the SMEs could improve the accuracy, validation data, productivity, and the competitiveness of enterprises. The problem of this research is how the SMEs accounting information systems in a cluster of Kampung Batik Laweyan Surakarta. To develop accounting information systems in a SMEs cluster of Kampung Batik Laweyan Surakarta, this research used research and development (R\&D) method. Data obtained through analysis of the company's business processes. Results of data analysis used to develop accounting information systems in a SMEs cluster of Kampung Batik Laweyan Surakarta. Accounting information system development consists of the structure of SMEs organizations, the general design of accounting information systems of the SMEs, flowchart and documentation of the SMEs accounting information systems, and accounting software of the SMEs
\end{abstract}

Keywords: SMEs, accounting information system, Batik

\section{Introduction}

\section{Research Background}

Research background in recent years, attention and initiatives aimed to the development of small and medium enterprise (SMEs). The role of SMEs in the economy of a country was quite strategic, however the tightness of the competition, has allowed the SMEs into disadvantageous position. But the majority of SMEs does business on traditional ways, so the opportunities that did not be utilized by SMEs. To improve the competitiveness, they must increase the speed and accuracy of decision making. It would realize with the availability of accurate and valid data. Accounting information system could be a solution for SMEs in their efforts to provide accurate and valid data. Previous studies showing that the usage of accounting information

Anita Wijayanti, SE., MM., Akt., Lecturer, Department of Economics, University of Islam Batik.

Kartika Hendra Ts, SE., M.Si., Akt., Lecturer, Department of Economics, University of Islam Batik.

Correspondence concerning this article should be addressed to Anita Wijayanti, Jl. KH Agus Salim, Number 10, Surakarta, Indonesia. E-mail: itax_solo@yahoo.com. 
systems by SMEs is still low (Amalia, 2012), one of the factors is accounting information system did not apply by (Widyastuti, 2012). SMEs need a proper accounting information system, which would apply by the SMEs (Wijayanti, 2010). SMEs in the batik industry in a cluster of Kampung Batik Surakarta Laweyan have the opportunity to develop their businesses, but many things are still facing a problem for SMEs in cluster of Kampung Batik Laweyan Surakarta. They need something to improve productivity, which it can improve their competitiveness trough improve the accuracy, validation of data, and the speed of decision making. Accounting information system is able to capture the problems in SMEs in cluster of kampung Laweyan Batik Surakarta (Wijayanti, 2010). Previous results mentioning that the level of accounting information system used by the SMEs in cluster Kampung Batik Laweyan Surakarta is only about 15\%. The previous research also found that the SMEs in cluster of Kampung Batik Laweyan Surakarta want to develop the accounting information system to improve their productivity (Wijayanti, 2010). This fact makes the researcher motivated to develop SMEs accounting information systems. SMEs accounting information systems were developed based on the characteristics of SMEs in cluster Kampung Batik Laweyan Surakarta.

\section{Research Problem}

The problem of this research is how the SMEs accounting information systems in a cluster of Kampung Batik Laweyan Surakarta. Based on current conditions, this research is attempting to answer the research problem.

\section{Objective Research}

The main of objective research is to develop SMEs accounting information systems in a cluster of Kampung Batik Laweyan Surakarta, while the specific objective of this research as follows:

- To examine the characteristics of SMEs in cluster of Kampung Batik Laweyan Surakarta and to develop the models of the SMEs accounting information system;

- To develop models of SMEs accounting information systems in a cluster of Kampung Batik Laweyan Surakarta.

\section{Literature Review}

\section{Accounting Information Systems}

Accounting information systems is a combination of one branch of accounting and information technology systems. Accounting information system is a combination of three words, systems, accounting, and information, which would interpret as a collection of some of the components or sub-systems that work together to achieve the goal (Wijayanti, 2011). Accounting information systems in performing activities that require specific elements that vary depending on the level of automation of the accounting information system (Wilkinson, 2000), a common model elements include the accounting information system end users, data sources, data collection, data processing, database management, information producers, and feedback (Hall, 2001).

\section{SMEs}

SME is defined as a type of business that has a maximum capital Rp 200,000,000, excluding land and buildings. In addition to maximum capital, according to the Indonesian law, UU No. 9, 1985, SMEs also has some characteristics that:

- have an annual sales turnover of Rp 1,000,000,000;

- owned Indonesian citizen; 
- independent, not subsidiaries or branches of companies that are not owned, controlled by, or affiliated directly or indirectly with medium or large business enterprise;

- form of business individuals, business entities are not incorporated, or incorporated business entity, including cooperatives.

\section{Model of Development System}

The development system is a set of activities, methods, results, and automated tools used to build and modify system information. Information system development is the science and art to do the design (designing) and the creation of information systems economically and elegantly (Beynon \& Williams, 2003). Development of the system would use to build a system that is completely new or improve existing system. Some of the systems development methodologies used in popular area are:

(1) Traditional, consists of two methods:

- Linear (waterfall model), this model is often called the classic life cycle. This method provides a systematic overview of the approach and sequential systems;

- Iterative incremental (prototyping), this method is one of the systems development directed to satisfaction of end users. This method directed to interaction between users and developers. Users usually only expressed a desire for the system in general, software development which will define the needs and desires of the users into a system design which later developed into the system.

(2) Non-traditional:

- Rapid Application Development (RAD), this model would call agile programming or extreme programming;

- RAD is a software development process that emphasizes the linear sequential cycle progression in a short time (60 to 90 days) with a component-based construction approach;

- End-user SDLC, method development done directly by the end-user. This method is becoming increasingly feasible with the availability of programming languages that are easier to use. The direct involvement of end-users is very beneficial, because really understand how the system works, it means the system analysis phase can be done more quickly;

- Framework for the Application of Systems Thinking (FAST), this method helps the development of systems that provides a mechanism for understanding and analyzing user requirements, conduct negotiations, the selection of a feasible solution, making the system more organized, until the implementation of the system.

\section{User Acceptance}

Level of user acceptance has been long known as one of the important point to determine whether a system can be categorized as a successful system or not. The researchers found several variables to explain acceptance of information technology (information technology acceptance). The two variables most acceptable is the TAM which consists of two variables user satisfaction (user satisfaction) and the use of the system (system usage) as well as variable end user computing satisfaction (EUCS) which consists of a variable convenience (ease of use) and benefits (usefulness) and contents, accuracy, format, ease, and timeliness.

\section{Research Method}

\section{Research Design}

The research design is as follows (see Figure 1): 


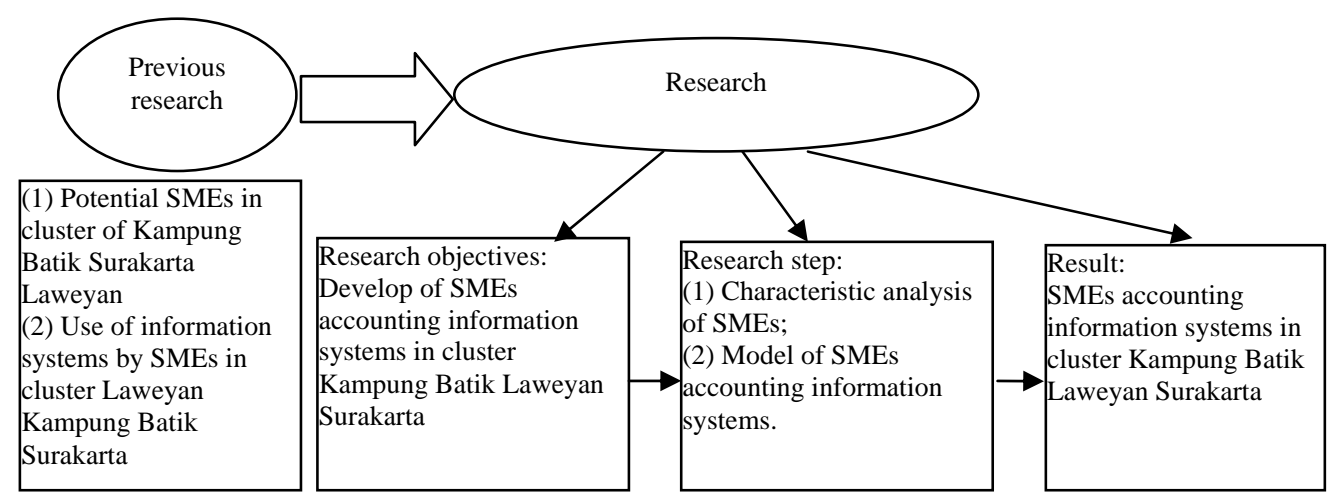

Figure 1. Research design.

\section{Object and Subject Research}

The object research is the SMEs accounting information systems. The subject research is SMEs in cluster of Kampung Batik Laweyan Surakarta.

\section{Data and Samples}

Data and samples in this study are used primary data. For the primary data, this research will collect data using by the questioner, participatory observations, and in-depth interview. The samples in this research are SMEs being the research pilot project. Pilot project in this research was 10 existing SMEs in cluster of Kampung Batik Laweyan Surakarta. Researcher's use these pilot project in the research were 10 existing SMEs in cluster Kampung Batik Laweyan Surakarta. Researcher usage these SMEs to be the pilot project because a previous study had been used at the site and SMEs which will be used as a pilot project already has a computer.

\section{Method for Data Analysis}

Method for data analysis research and development (R\&D) methods is used to develop the SMEs accounting information system. Data collected, and analyze to allow the characteristics of SMEs in cluster of Kampung Batik Laweyan. To develop the model of the SMEs accounting information system, this research emphasizes the involvement of the target as the subject of active research, making their experience as an integral part in the research, find the problem and solutions in the context of the empowerment of the target goal. Element of participation and involvement of the target group would be the most important in this study. The target group, researchers and practitioners would constantly together develop the SMEs accounting information systems. The model would be implemented in SMEs using accounting information software, which also compiled in this research

\section{Result and Discussion}

\section{Characteristics of SMEs in Cluster Kampung Batik Laweyan Surakarta}

(1) Business process SMEs in cluster Kampung Batik Laweyan Surakarta, in accounting cycle called revenue cycle, expenditure cycle, production cycles, cycles of fixed assets, and payroll cycles.

(2) Results of in-depth interviews conducted research also illustrates that the owners or managers of SMEs in cluster Kampung Batik Laweyan Surakarta generally run a company based on instinct and the habit. All decisions are in the hands of the owners, so management does not stand alone. SMEs in the cluster Kampung Batik Laweyan Surakarta, did not have a clear organizational structure and do not have a clear separation of 
duties over the functions within the company, both functional, and operational administration.

(3) The characteristics of SMEs to the accounting information system, measurement of the correlation between the variables of TAM, end user computing satisfaction (EUCS), and user acceptance. Variables in the TAM is usefulness, ease of use, while the variables in the EUCS is content, accuracy, form, ease, and timeliness. From the questioner has been sent to the SMEs, 45 questioners usable, according to completeness of the analysis. Correlation test is a test used to measure the relationship between two variables in a linear fashion to determine the direction of the relationship. If the correlation coefficient is more than 0.5 , then the relationship is strong, whereas if it is less than 0.5 , then the relationship is weak. The correlation between variables showed the following results (see Table 1).

Table 1

Correlation Test Results

\begin{tabular}{llll}
\hline Variables & Coefficient & Signification & Correlation \\
\hline Usefulness & 0.520 & 0.5 & Strong \\
Ease of use & 1.000 & 0.5 & Strong \\
Content & 0.408 & 0.5 & Weak \\
Accuracy & 0.351 & 0.5 & Weak \\
Format & 0.319 & 0.5 & Weak \\
Ease & 0.253 & 0.5 & Weak \\
Timeliness & 0.533 & 0.5 & Strong \\
\hline
\end{tabular}

The results of the correlation test, demonstrate that the variable usefulness, ease of use and timeliness has a strong association with user acceptance. The contents, accuracy, form; convenience (ease) has a weak relationship with the user acceptance. The results of in-depth interviews, that variable ease of use to be the most variable of the relationship with the user acceptance. To develop the SMEs accounting information system in the cluster Kampung Batik Laweyan Surakarta, shall provide convenience for SMEs, to perform data input, data processing, and searching for data.

The development of SMEs accounting information systems should be able to increase the productivity of SMEs. The system developed to be real time.

Other variables that have weak correlation such content, accuracy, form, simplicity (ease), still must be considered in developing of the SMEs accounting information system in cluster Laweyan Kampung Batik Surakarta, so that the system strictly in accordance with the needs and desires of SMEs, so that they can use and take advantage of the system to be developed.

\section{Model of SMEs Accounting Information Systems}

The model of SMEs accounting information systems can be seen in the following:

(1) Organizational Structure of SMEs.

The organizational structure is in need of SMEs that can definitely work best knowledge of each party involved in the management of SMEs. The organizational structure of SMEs had not formally established.

Prepare the SME information systems require separation of duties between departments in the management of SMEs so before preparing accounting information systems, it is a necessary organizational structure of SMEs. Based on the above the company's organizational structure described in general in Figure 2. 


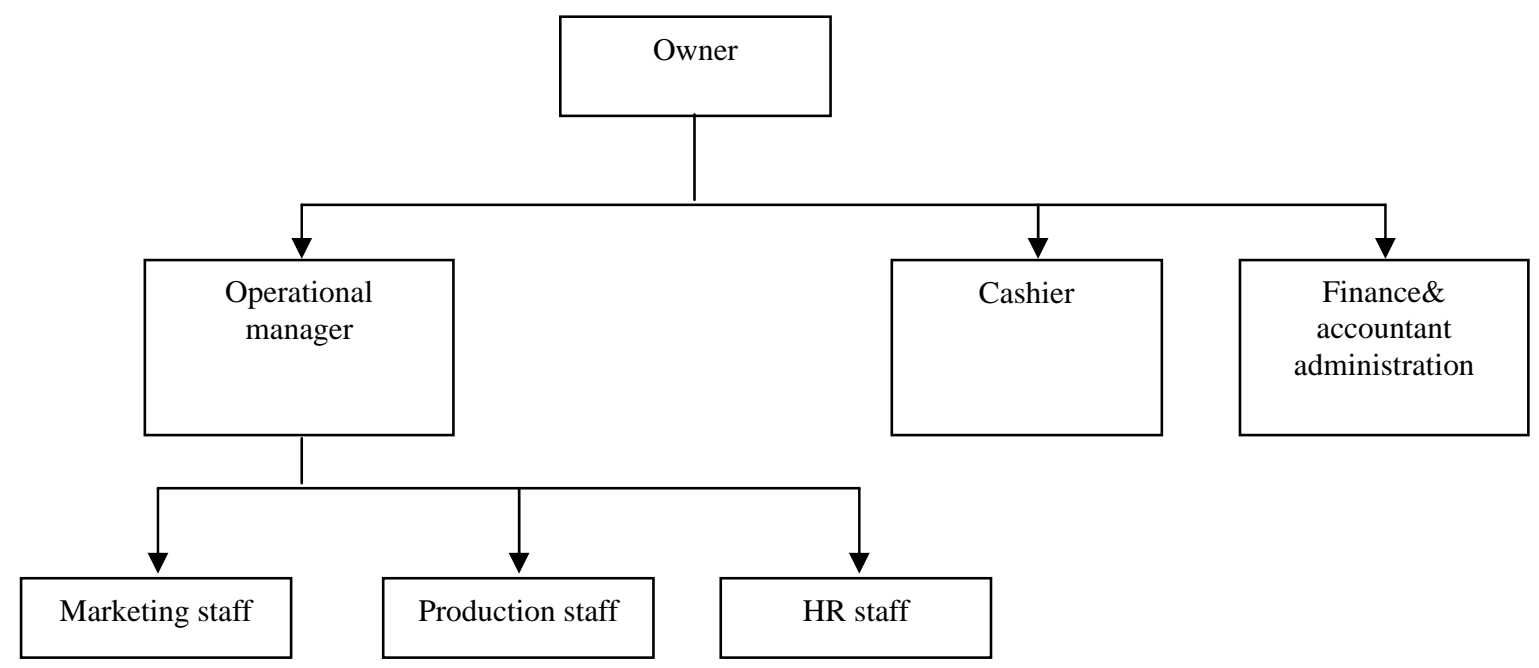

Figure 2. Organizational structures of SMEs in cluster of Kampung Batik Surakarta Laweyan.

(2) General design of SMEs accounting information systems.

SMEs accounting information developed by four sub-systems they are purchasing subsystem, cash subsystem, sales subsystem, and general ledger support systems (see Figure 3).

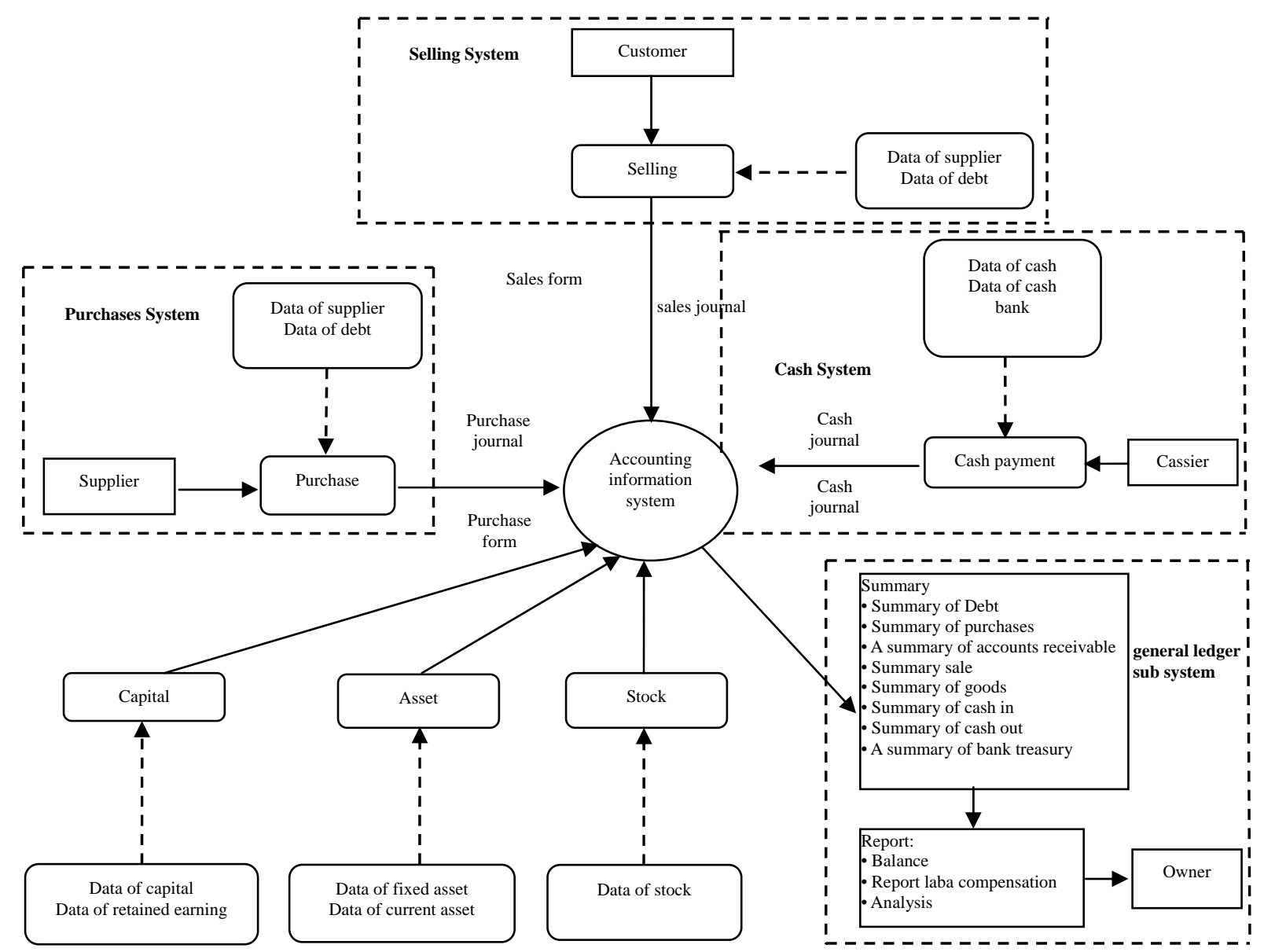

Figure 3. Design of SMEs accounting information systems in cluster of Kampung Batik Surakarta Laweyan. 
(3) Flowchart of SMEs accounting information systems.

The flowchart of sales system, cash system, purchasing system, and ledger system you can see in Figures 4, 5,6 , and 7 .

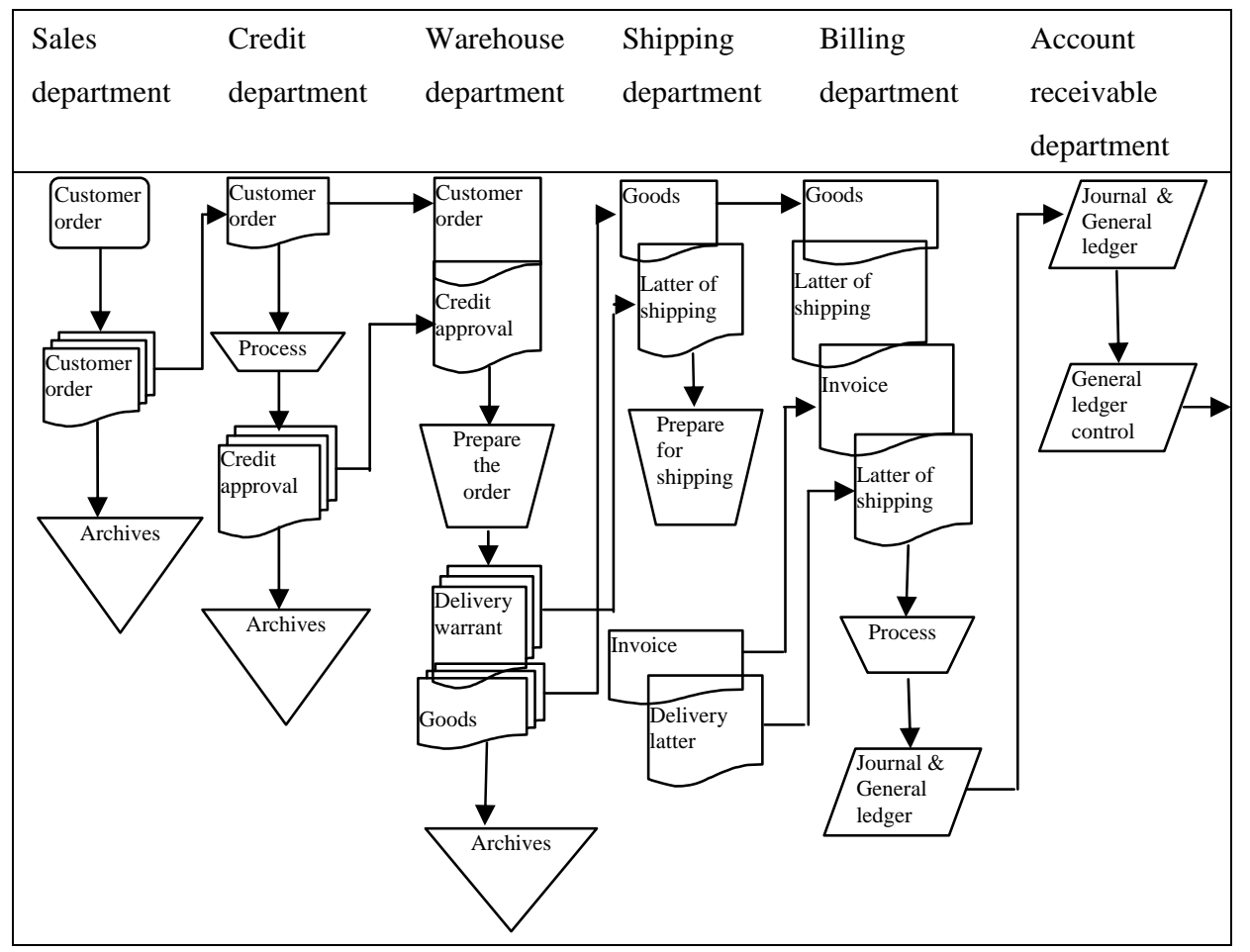

Figure 4. Flowchart of sales system.

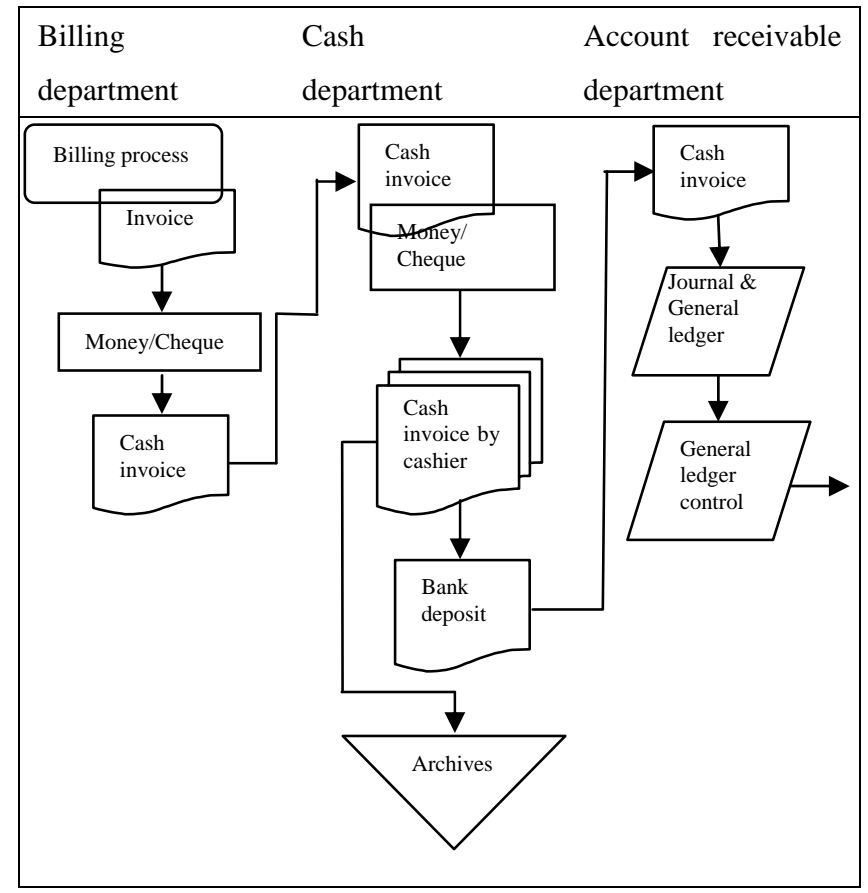

Figure 5. Flowchart of cash system. 


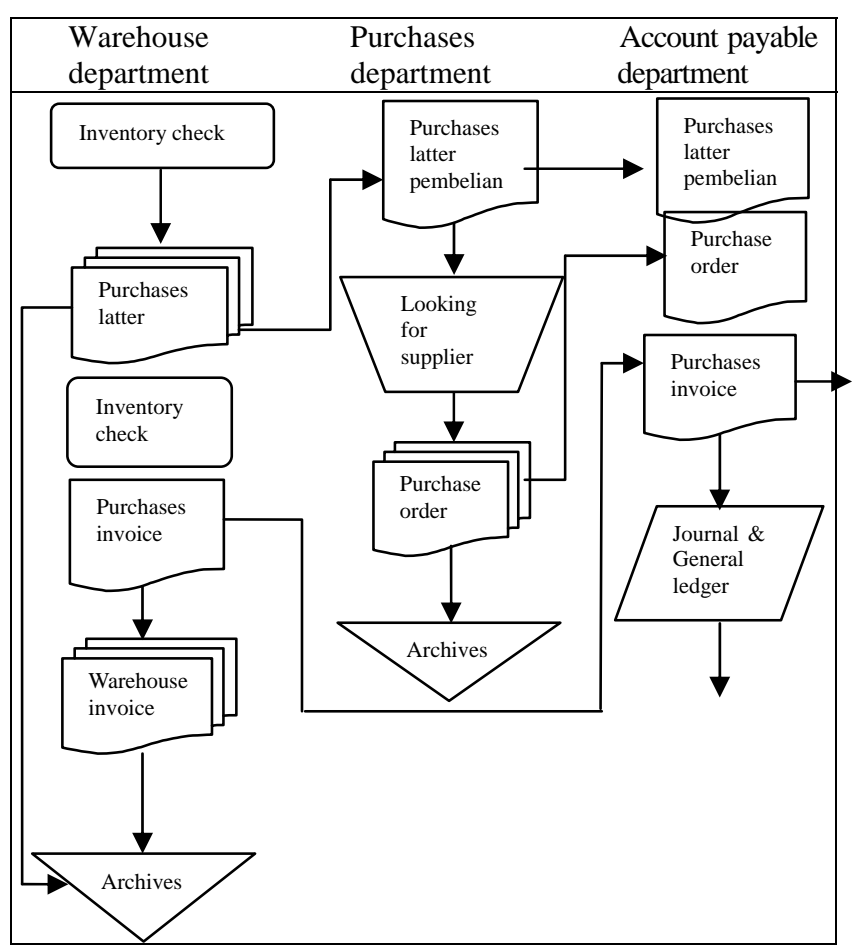

Figure 6. Flowchart of purchasing systems.

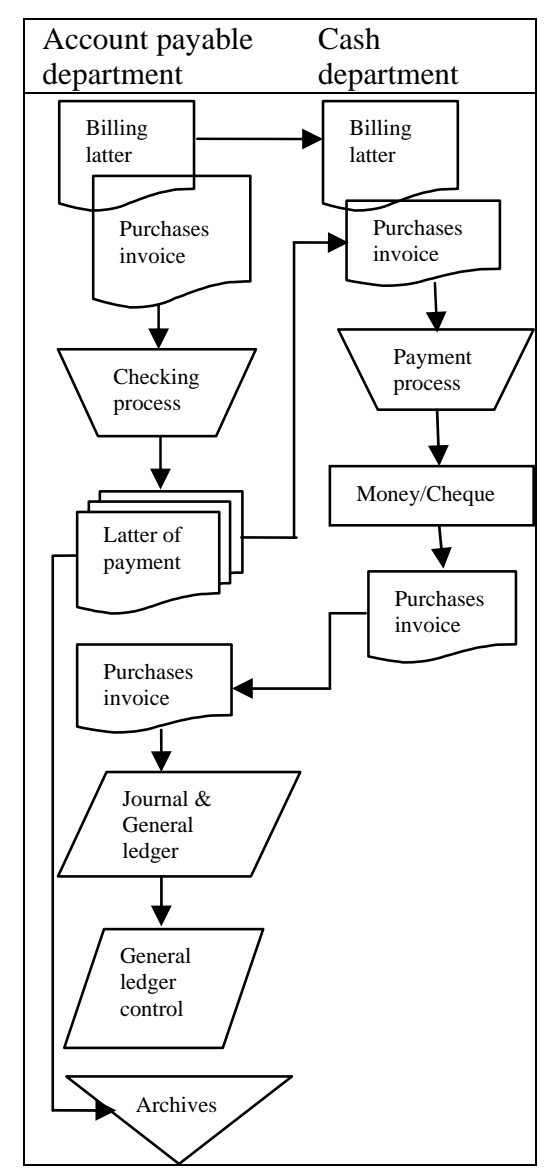

Figure 7. Flowchart of payment system. 
(4) SMEs accounting information system database (see Figure 8).

\begin{tabular}{|ll|}
\hline tb_Journal \\
$\checkmark$ & journal_number \\
$\checkmark$ & journal_code \\
account_number \\
debet & \\
credit & \\
\hline tb_balance akun \\
$\checkmark$ & account_code \\
beginning balance end balance \\
$\checkmark$ & mount \\
$\checkmark$ & year \\
$\checkmark$ & flag \\
\hline
\end{tabular}

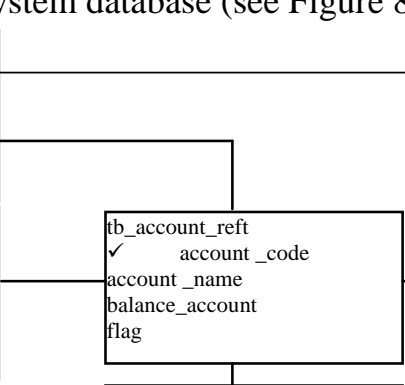

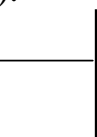

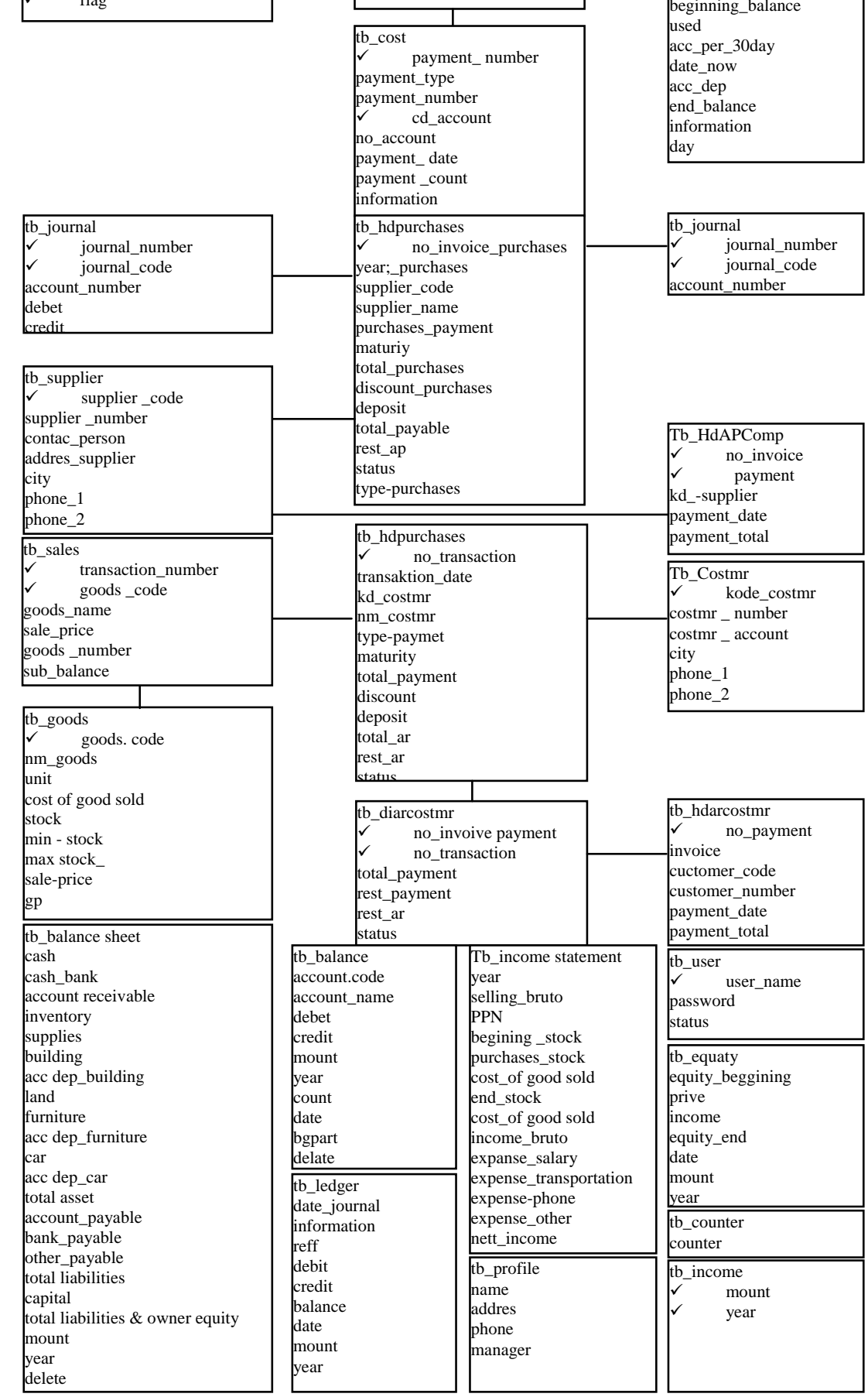

Figure 8. SMEs accounting information system database. 
(5) SMEs accounting information systems software.

Based on the results of the form design, this research developed SMEs accounting information systems software. The display SMEs accounting information systems software are as follows in Figures 9, 10, 11, 12, 13, 14, 15, 16, and 17.

NONER REXNIS:

RANG REKENINS:

Sent

TABEL REKENNNG

\begin{tabular}{lll}
\hline NO REKENING & REKENING & BESAR \\
\hline 5000 & PENOAFATAN & 0 \\
\hline 4000 & BLAYA & 0 \\
\hline 3000 & MOTR & 0 \\
2000 & HUNTANG & 0 \\
1500 & PERSEDLSAN & 0 \\
1400 & ASSET & 0
\end{tabular}

Figure 9. Account of financial statement.

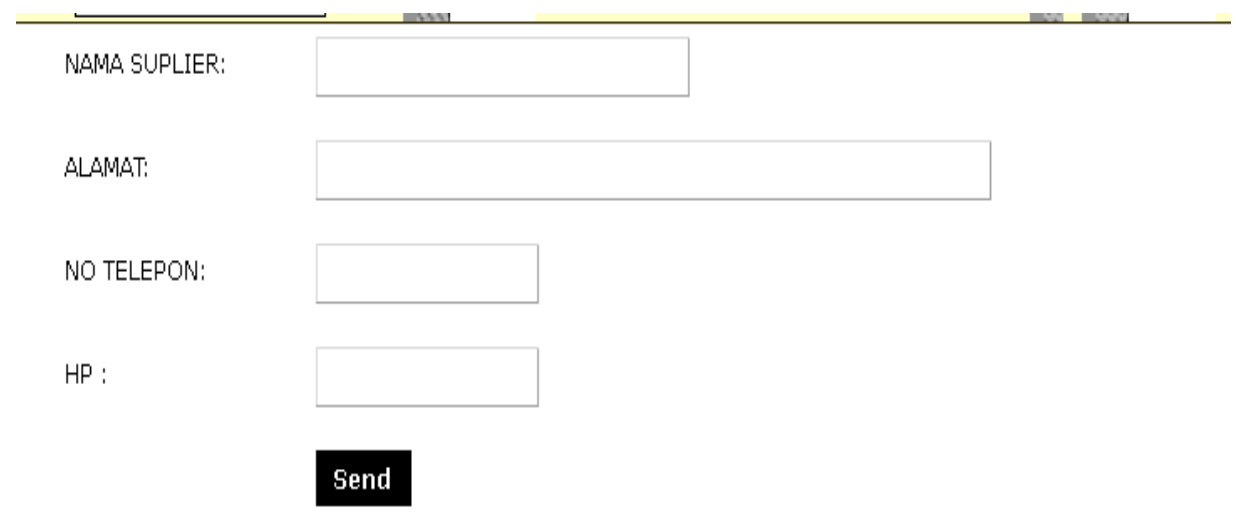

PILIH SUPLIER

\begin{tabular}{|llllll|}
\hline NO & NAMA SUPLIER & ALAMAT & TELEPON & HP & BELI \\
\hline 3 & BATIK WIJAYANTI & JL, SIDOMUKTI NO 49 & $0271-714336$ & 0812345567 & 0 \\
\hline 2 & DIDIK & JL MAKMUUR ABADI & 898989898 & 88686688688 & 0 \\
\hline 1 & ANITA & JL BAKI & 779797977 & 80909090909 & 0 \\
\hline
\end{tabular}

Figure 10. Supplier data input. 


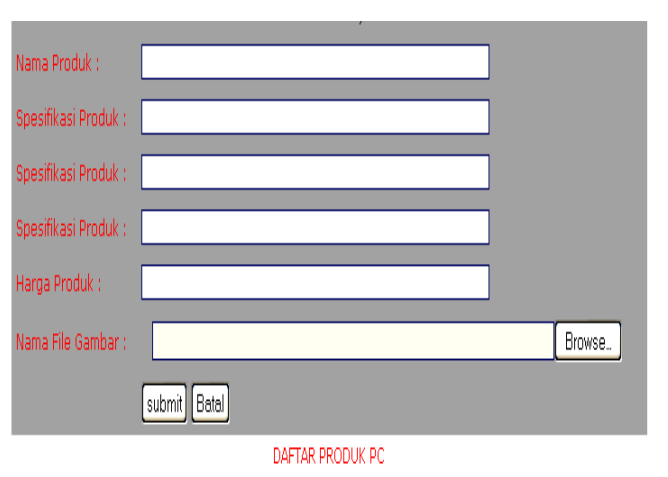

\begin{tabular}{|c|c|c|c|c|c|c|}
\hline & ID & ProDuK & SPEK & HARGA & GANTI & HAPUS \\
\hline & 18 & $\begin{array}{l}\text { HEM PRIA LENGAN } \\
\text { PANLDANG }\end{array}$ & LENGGN PANDANG MOTIF CAKGR & 75000 & [ & $x$ \\
\hline 2. & $\underline{16}$ & HEM PRIA & LENGGN PENDEK MOTF KLITIK & 55000 & & $x$ \\
\hline 3. & $\underline{14}$ & BAU BATKK & 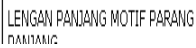 & 35000 & [] & $x$ \\
\hline
\end{tabular}

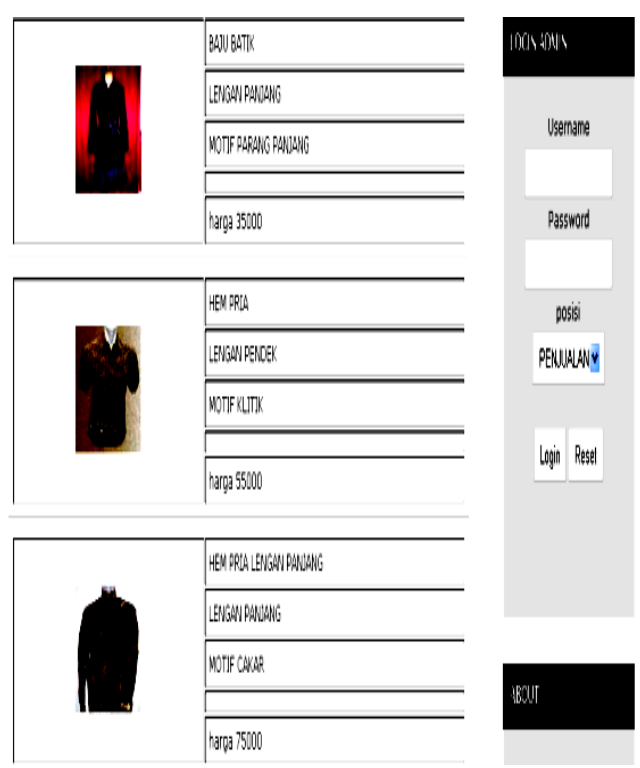

Figure 11. Input of inventory data.

\begin{tabular}{ll} 
NO BUKTI: & 11 \\
NAMA SUPLIER: & BATIK WIJAYANTI \\
NAMA SUPLIER: & BATIK WIJAYANTI \\
ALAMAT: & JL. SIDOMUKTI NO 49 \\
NO TELEPON: & O271-714336 \\
HP : & 0812345567 \\
KOdE / Nama Barang : & $14-B A J U$ BATIK \\
JUMLAH: & \\
HARGA SATUAN: & \\
\hline
\end{tabular}

Figure 12. Input of purchasing transaction.

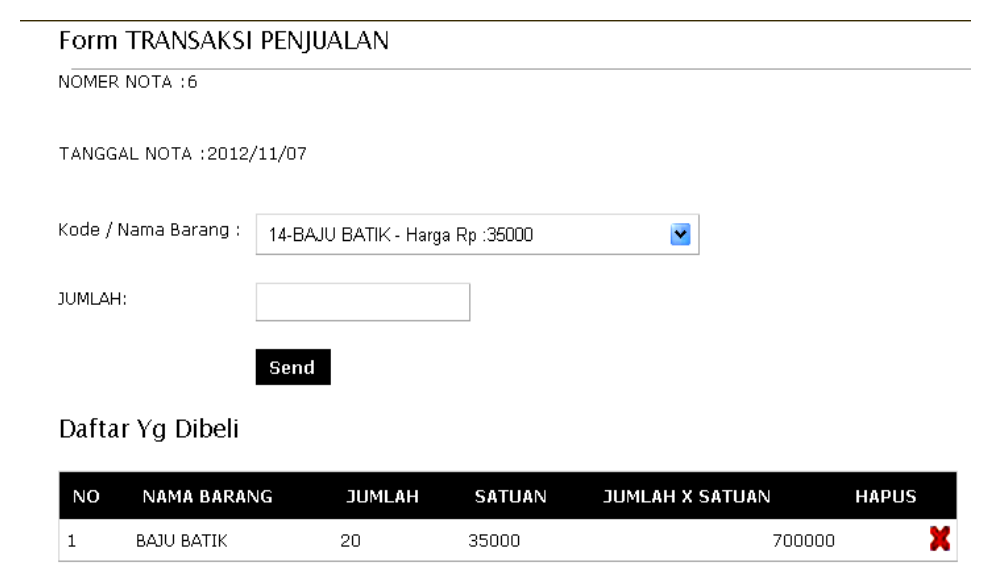

Figure 13. Input of selling transaction. 
TANGGAL NOTA :07/11/2012

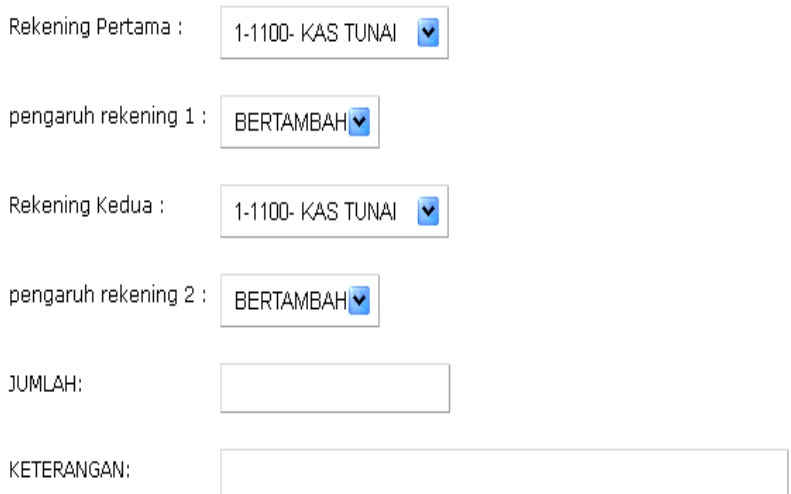

Send

Figgure 14. Journal.

\begin{tabular}{|c|c|c|c|c|c|c|}
\hline \multicolumn{7}{|c|}{ BATIK KENCANA MURNI } \\
\hline \multicolumn{7}{|c|}{ LAPORAN BUKU BESAR } \\
\hline \multicolumn{7}{|c|}{ Dari Ha. Pekkiran 1101001 sid 7105} \\
\hline \multicolumn{7}{|c|}{ Periode: M:012012 sid 3101:2012 } \\
\hline Ig No. Buki & Uraian & $\mathrm{cc}$ & Perk. Pernbantu & Debet & Kreadit & Saldo \\
\hline \multicolumn{7}{|c|}{ Na. Pekkiran: 1101001 -Kas Kecil } \\
\hline \multicolumn{7}{|c|}{ Saldo Aval .......................... } \\
\hline & & & & & & $3.300 .000,00$ \\
\hline \multicolumn{7}{|c|}{ Na. Perkiran: 1101002-Kas Besar } \\
\hline \multicolumn{7}{|c|}{ Saldo Anal ................................. } \\
\hline & & & & & & $3.000 .000,00$ \\
\hline \multicolumn{7}{|c|}{ No. Perkiraan: 1102001 - Bank BCARp 001-3020121 } \\
\hline \multicolumn{6}{|c|}{ 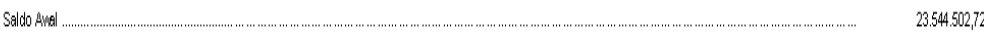 } & $23.54,502,72$ \\
\hline 1501112 в8M,0000101 & Pelunasan Inwioe INY0020107 107 & & & $9.400 .000,00$ & 0,00 & $32.944 .502,72$ \\
\hline 2501112 86k00000101 & Biaja gail & & & 0,00 & $5,000,000,00$ & $27.944 .502,72$ \\
\hline \multirow[t]{2}{*}{ 3101/12 8890,0000301 } & Bunga jasa giro & & & $15,000,00$ & 0,00 & $27.959 .502,72$ \\
\hline & Tdal Ho. Perkiraan 1102001: & & & $9.415 .000,00$ & $5.000 .000,00$ & $27.959 .502,72$ \\
\hline
\end{tabular}

Figure 15. General ledger.

\begin{tabular}{|c|c|c|c|c|}
\hline \multirow[b]{2}{*}{ Keterangan } & \multicolumn{2}{|c|}{$\begin{array}{c}\text { BATIK KENCANA MURNI } \\
\text { Laba/Rugi } \\
\text { 31 Januari } 2012\end{array}$} & \multirow[b]{2}{*}{ HaikTurun } & \multirow[b]{2}{*}{$\%$} \\
\hline & sid Januari 2011 & sid Januari 2012 & & \\
\hline \multicolumn{5}{|l|}{ PENDAPATAN } \\
\hline Pendapatan Operasi & $45.500 .000,00$ & $(0,00)$ & $(45.500 .000,00)$ & $(1,00)$ \\
\hline Potongan Penjualan & $(2.000 .000,00)$ & $(0,00)$ & $2.000 .000,00$ & $(1,00)$ \\
\hline TOTAL PEMDAPATAN & $43.500 .000,00$ & $(0,00)$ & $(43.500 .000,00)$ & $(1,00)$ \\
\hline \multicolumn{5}{|l|}{ HPPßBEBAN USAHA LANGSUHG } \\
\hline Persediaan Angl & $(25.000000,00)$ & $(0,00)$ & $25.000 .000,00$ & $(1,00)$ \\
\hline Pembelian & $(11.000000,00)$ & $(0,00)$ & $11.000 .000,00$ & $(1,00)$ \\
\hline Persediaan Yang Tersedia Untuk Dijual & $(36.000000,00)$ & $(0,00)$ & $36.000 .000, \infty$ & $(1,00)$ \\
\hline Persediaan Akhir & $22.000 .000,00$ & $(0,00)$ & $(22.000 .000,00)$ & $(1,00)$ \\
\hline Harga Pokok Penjualan & $(14.000,000,00)$ & $(0,00)$ & $14.000 .000,00$ & $(1,00)$ \\
\hline Beban Uscha Langsung & $(5.000 .000,00)$ & $(0,00)$ & $5.000 .000,00$ & $(1,00)$ \\
\hline TO TAL HPP/BEB AN USAHA LAHGSUHG & $(19.000 .000,00)$ & $(0,00)$ & $19.000 .000,00$ & $(1,00)$ \\
\hline LABAKOTOR & $24.500 .000,00$ & $(0,00)$ & $(24.500 .000,00)$ & $(1,00)$ \\
\hline
\end{tabular}

Figure 16. Income statement. 


\begin{tabular}{|c|c|c|c|c|c|}
\hline \multicolumn{6}{|c|}{$\begin{array}{l}\text { BATKK KENCANA MURNI } \\
\text { NERACA SALDO } \\
31 \text { Januari } 2012\end{array}$} \\
\hline No. Perk. & Keterangan & Saldo Awal & Debet & Kredit & Saldo Akhir \\
\hline 1101001 & Kas Kecil & 3.300 .00000 & 0,00 & 000 & $3,300000,00$ \\
\hline 1101002 & Kas Besar & 3000.00000 & 0,00 & 000 & 3000000,00 \\
\hline 1102001 & Bank B CA Rp 001-3020121 & $23544.502,72$ & $9.415000,00$ & 5.000 .00000 & $27959.502,72$ \\
\hline 1102002 & Bank BCA USD 0 035-3333333 & 59810.98800 & $4.000000,00$ & 14.400 .00000 & $49.410 .988,00$ \\
\hline 1104 & Piutang Dagang & 97.765 .33380 & $43.500000,00$ & 10.000 .00000 & $131265,333,80$ \\
\hline 1110 & Piutang Lain-Lain & 600000.00000 & 0,00 & 000 & 600000000,00 \\
\hline 1114999 & Uang Muka Lain-Lain & 1320.00000 & 0,00 & 000 & $1,320000,00$ \\
\hline 1116003 & Biayle Sewa Dibayar Di Muka & 6000.00000 & 0.00 & 000 & 6000000,00 \\
\hline 1118003 & PPh 23 Dibayer Di muka & $1019.552,40$ & 0,00 & 000 & 1019552,40 \\
\hline 1120 & Persediaan Barang & 10000.00000 & $22.000000,00$ & 25.000 .00000 & 7000000,00 \\
\hline 1301 & Tanah & 100000.00000 & 0.00 & 000 & 100000000,00 \\
\hline 1302 & Bangunan & 133000.00000 & 0.00 & 000 & 133000000,00 \\
\hline 1303 & Kendaraan & 30000.00000 & 0,00 & 000 & $30000.000,00$ \\
\hline 1304001 & Peralatan Kantor Fumiture & 28.100 .00000 & $23.600000,00$ & 000 & $51.700 .000,00$ \\
\hline 1304002 & Peralatan Kantor Logam & 4.140 .00000 & $4.140000,00$ & 000 & 8280000,00 \\
\hline 1304003 & Peralatan Kantor Komputer \& Printer & 90330.009 .80 & $90.330009,60$ & 000 & $180,660019,20$ \\
\hline 1304004 & Peralatan Kantor Sotware & 10000.00000 & 0,00 & 000 & $10000.000,00$ \\
\hline
\end{tabular}

Figure 17. Balance sheet.

\section{Conclusions and Recommendations}

\section{Conclusions}

The analysis of SMEs in cluster Kampung Batik Surakarta Laweyan provides an overview as a basis for the design of the SMEs accounting information system. SMEs accounting information system which includes SMEs organizational structure, SMEs the general design of the accounting information systems, flowchart of each system, document system, database, and SMEs accounting information systems software.

\section{Recommendations}

Future research, the SMEs accounting information system used in the business process of the company, and the research measurement the productivity of SMEs accounting information system and audit information system in SMEs.

\section{References}

Amalia, R. (2012). Effect of accounting information systems users against improved managerial performance in banking company in Makasar (Pengaruh Pengguna Sistem Informasi Akuntansi Terhadap Peningkatan Kinerja Manajerial Pada Perusahaan Perbankan di Makasar). Retrieved from http://repository.unhas.ac.id

Beynon, D. P., \& Williams, M. D. (2003). The diffusion of information systems development methods. Journal of Strategic Information Systems, 12, 29-46.

Bodnar, G. H., \& Hopwood, W. S. (2004). Accounting information system (9th ed.). New Jersey: Prentice-Hall, Inc..

Brown, I. T. J. (2002). Individual and technological factors affecting perceived ease of use of web-based learning technologies in developing country. The Electronic Journal on Information Systems in Developing Countries, 9(5), 1-15.

Hall, J. A. (2001). Accounting information systems (3rd ed.). Cincinnati: Shout-Western College Publishing.

Krismiaji. (2005). Accounting information system (Sistem Informasi Akuntansi). Jogyakarta: Akademi Manajemen Perusahaan YKPN.

Mizar, M. A., \& Muchjidin, M. (2008). Typology and characteristics of technology adoption in small industrial processing of agricultural products (Tipologi Dan Karakteristik Adopsi Teknologi Pada Industri Kecil Pengolah Hasil Pertanian). Proceedings from Gelar Teknolog dan Seminar Nasional Teknik Pertanian 2008 di Jurusan Teknik Pertanian. Fakultas Teknologi Pertanian UGM.

Noertjahyana, A., \& Gregorius, S. B. (2003). Designing and development production information systems determination of cost of production in tire retreading company in Surabaya (Perancangan Dan Pembuatan Sistem Informasi Produksi Dan 
Penentuan Harga Pokok Produksi Pada Perusahaan Vulkanisir Ban Di Surabaya). Jurnal Informatika, 4(2), 57-64.

Nugraha, D. (2003). The information technology systems (Mengenal Sistem Teknologi Informasi). Retrieved from http://www.ilmukomputer.com

Nur, I. (2010). Information systems development method (Metode Pengembangan Sistem Informasi). Retrieved from http://nurichsan.blog.unsoed.ac.id/2010/11/19/metode-pengembangan-waterfall-prototyping

Potecea, O., Gabroveanu, E., \& Radneantu, N. (2009). Accounting information power instrument for advanced management in knowledge based organizations. Retrieved from http://mpra.ub.uni-muenchen.de/14042/1/MPRA_paper_14042

Reid, G. C. (2012). Information system development in the small firm. Retrieved from http://ees.elsevier.com

Riemenschneider, C. K., \& Mykytyn, P. P. (2000). What small business executives have learned about managing information technology. Information and Management, 37, 257-269.

Surmen, Y., \& Abdulkarim, D. (2005). The relationship between the historical development of the accounting information system and its applications and information technologies. Retrieved from http://journal.mufad.org/attachments/article/464/21.pdf

Widyastuti, D. (2012). Pengaruh Penerapan Sistem Informasi Akuntansi Terhadap Peningkatan Kinerja Manajerial dengan Ketidakpastian Lingkungan Sebagai variabel Moderating. Retrieved from http://etd.eprints.ums.ac.id

Wijayanti, A. (2010). Pemetaan Bisnis Keluarga di Kampung Batik Laweyan Surakarta. Unpublished Research, Universitas Islam Batik Surakarta.

Wijayanti, A. (2011). Sistem Informasi AKuntansi: Pendekatan Pengembangan pada UKM. Surakarta: Universitas Islam Batik Surakrta Press.

Wilkinson, J. W. (2000). Accounting information systems (4th ed.). New York: John Wiley \& Son. 